\title{
МАШИНИ, ОБЛАДНАННЯ ТА МАТЕРІАЛИ
}

УДК 622.276 .054

DOI: $10.31471 / 1993-9965-2018-1(44)-81-88$

\section{ВДОСКОНАЛЕННЯ ТА ДОСЛІДЖЕННЯ РІЗЬБОВОГО З'ЄДНАННЯ НАСОСНИХ ШТАНГ}

\author{
В.В. Михайлюк, А.Р. Юрич, Р.О. Дейнега, Р.С. Кравчук, Р.А. Пінчак, Б.В. Харламов \\ ІФНТУНГ; 76019, м. Івано-Франківськ, вул. Карпатська 15; тел. (0342) 727126, \\ e-mail: no@nung.edu.ua
}

На основі аналізу літературних джерел встановлено, щчо відмови різьбового з'єднання насосних штанг є найбільш розповсюдженими і перевищують третину від загальної кількості відмов елементів штангової колони. Це пов'язано з тим, шо в різьбовому з'єднанні насосних штанг навантаження по витках різьби розподілясться нерівномірно.

Виконано імітаційне моделювання стандартної конструкиї̈ з'єднання насосних штанг та побудовано графічні залежності розподілу напружень по впадинах різьби ніпеля.

Проведено огляд способів зменшення нерівномірності навантаження по витках різьби з'єднання насосних итанг.

Запропоновано конструкиію з'єднання насосних штанг, в якій різьба ніпеля має змінний середній діаметр, щз реалізується за допомогою додаткового елементу, встановленого з натягом в отвір тіла ніпеля. Порівняння залежностей розподілу напружень по впадинах різьби ніпеля стандартної та запропонованоі конструкиій з'єднань показує спад напружень у першій впадині витка ніпеля на величину близько 60 МПа, а в третьому та наступних витках напруження зростають та вирівнюються за величиною. Така зміна напружень по впадинах витків позитивно впливатиме на роботу з'єднання насосних шттанг при дії цииклічного навантаження під час його експлуатаиії у свердловині.

Ключові слова: насосна штанга, напруження, напружено-деформований стан, різьба, імітаційне моделювання

На основе анализа литературных источников установлено, что отказы резьбового соединения насосных иттанг наиболее распространены и превышают треть от общего количества отказов элементов штанговой колонны. Это связано с неравномерностью распределения нагрузки по виткам в резьбовом соединении насосных шттанг.

Выполнено имитационное моделирование стандартной конструкции соединения насосных штанг и построены графические зависимости распределения напряжений по впадинам резьбы ниппеля.

Проведен обзор способов уменьшения неравномерности нагрузки по виткам резьбы соединения насосных иттанг.

Предложена конструкиия соединения насосных итанг с переменным средним диаметром резьбы ниппеля, который реализуется с помощьью дополнительного элемента, установленного с натягом в отверстие тела ниппеля. Сравнение зависимостей распределения напряжений по впадинам резьбы ниппеля стандартной и предложенной конструкиии соединения показывает падение напряжений в первой впадине витка ниппеля на величину около 60 МПа, а в третьем и следующих витках напряжения растут и выравниваются по величине. Такое изменение напряжений по впадинам витков будет положительно влиять на работу соединения насосных итанг при воздействии циклической нагрузки при его эксплуатации в скважине.

Ключевые слова: насосная штанга, напряжение, напряженно деформированное состояние, резьба, имитационное моделирование

On the basis literary sources analysis, it was defined, that failures of the pump rod threaded connections are the most common exceed one-third of the total number of the rod string failures. It is due to non-uniform load distribution across thread turns of the pump rod threaded connections.

The simulation modelling of standard design of pump rods was performed and graphic dependencies of stress distribution were developed on the gaps the pump rod threaded connections. 
The methods to reduce load non-uniformity across thread turns of the pump rod threaded connections were considered.

The design of the pump rod connection was proposed; it shall have the variable mean diameter of the nipple thread by adding one more element, fitted in the nipple body hole. The comparison of stress distribution dependencies on the gaps the pump rod nipple of the standard and proposed design showed that stress decrease in the first gap of the thread turn by $60 \mathrm{MPa}$, and in the third and next turns stresses increases and become uniform by the value. This change of stresses on turn gap, when it is operated in the well.

Keywords: pump rod, stress, stressed-deformed state, thread, simulation modelling

\section{Bcmyn}

На даному етапі розвитку нафтогазової промисловості існує декілька способів видобування нафти, але, виходячи з можливостей їх реалізації і застосування, найбільш поширеним на родовищах України є глибинно-насосний із використанням різного виду насосів. Більшість нафтових свердловин експлуатуються штанговими свердловинними насосними установками (ШСНУ), за допомогою яких видобувається близько 50 \% всієї нафти. Це пояснюється відносною простотою конструкції ШСНУ та зручністю в експлуатації.

Проте, як показують промислові дані, під час експлуатації ШСНУ мають місце численні відмови їх свердловинного обладнання, в тому числі і різьбових з'єднань колон насосних штанг (КНШ). Напружено-деформований стан різьбового з'єднання КНШ визначається характером розподілу навантажень по витках різьби, який $є$ нерівномірним і залежить від багатьох чинників. Зважаючи на це дослідження, вдосконалення існуючих та розроблення нових конструкцій різьбових з'єднань та заходів для підвищення їх експлуатаційних характеристик $є$ актуальним завданням, що потребує вирішення.

\section{Мета роботи та обгрунтування необ- хідності їі виконання}

Мета роботи полягає у підвищенні ефективності експлуатації різьбового з'єднання насосних штанг (НШ) шляхом вдосконалення існуючої конструкції та оцінки їі напруженодеформованого стану.

Завдання роботи:

1) проаналізувати: відмови різьбових з'єднань насосних штанг, їх напружено-деформований стан, способи зменшення нерівномірності розподілу навантажень по витках різьби;

2) вдосконалити існуючу конструкцію різьбового з'єднання насосних штанг;

3) порівняти напружено-деформовані стани існуючої та вдосконаленої конструкцій різьбових з'єднань насосних штанг.

\section{Аналіз попередніх досліджень і публікацій}

\footnotetext{
Аналіз відмов різьбових з'єднань насосних штанг

Як свідчать статистичні дані $[1,2]$, відмо-

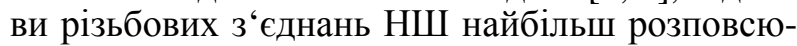
джені і складають більше $30 \%$ (не враховуючи відгвинчування 3“єднання і обриви тіла муфт) від загальної кількості відмов штангової колони. Це пов'язано 3 тим, що в різьбовому 3“єднанні [3] насосних штанг навантаження по
}

витках різьби розподіляється нерівномірно. Відомо, що у з'єднаннях такого типу навантаження зростає від останніх до перших витків за законом гіперболічного косинуса, причому на перші два витки припадає від 38 до $47 \%$ загального навантаження [3].

3'єднання НШ [4] мають конструктивні елементи (розвантажувальну канавку, зрізи перших витків тощо), які призначені для зменшення навантаження на перші витки. Однак дослідження $[1,2,4,5]$ підтверджують, що бі-

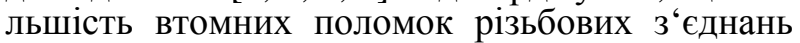
НШ таки відбуваються по перших впадинах витків різьби ніпеля.

З'єднання НШ сконструйоване як різьбове упорне фрикційне з'єднання. Оскільки втомна міцність з' єднання низька при дії на нього циклічних навантажень, то необхідно обмежувати ïх величини за допомогою попереднього натягу різьби. Якщо попередній натяг різьби НШ $є$ більшим ніж прикладене навантаження, то напруження в з'єднанні змінюватиметься у невеликому діапазоні, що позитивно впливає на його роботу. Сила тертя між поверхнями упорних торців НШ та муфти замикає з'єднання і запобігає його саморозгвинчуванню. Проте, якщо попередній натяг менший від прикладеного навантаження, то упорний торець різьби НШ від'єднається від торця муфти під час циклічного руху колони, що призведе до його руйнування. В загальному втрата натягу може виникати внаслідок недостатнього моменту згвинчування, змащування, невідповідного обслуговування, розбалансування, зношування поверхні муфти, ударів з'єднання НШ по насоснокомпресорних трубах або будь-якої комбінації цих чинників.

При роботі колони НШ в умовах циклічного навантаження нерідко спостерігається поява втомних тріщини в першій впадині повного витка різьби ніпеля.

Також спостерігається руйнування муфт посередині їх довжини. При руйнуванні муфт втомна тріщина, як правило, зароджується на зовнішній поверхні муфти, просувається всередину у напрямку витків різьби та поширюється через тіло, утворюючи злам. Такі злами характерні для руйнувань муфт і спричинені механічним пошкодженням іiі поверхні, перевищенням границі втомної міцності матеріалу муфт або дефектами під час виготовлення.

Руйнування муфт від втрати натягу різьбового з'єднання відбувається у впадині різьби муфти напроти першого повного витка різьби ніпеля.

До руйнування різьбових з'єднань НШ призводить також зношування різьби (як ніпеля 


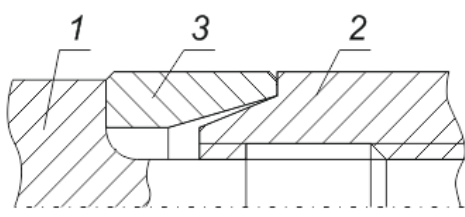

a)

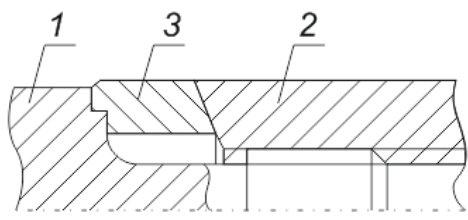

B)

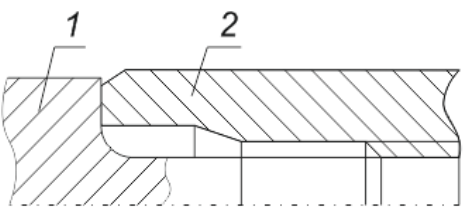

б)

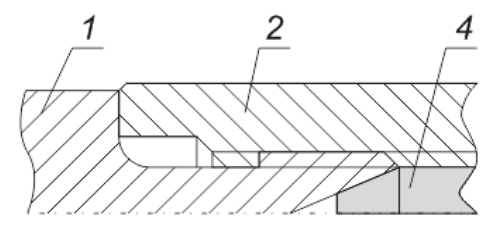

г)

1 - итанга; 2 -муфта; 3 - протекторна вставка; 4-конусна вставка; $a-$ з'єднання із застосуванням муфти стиску-розтягу; б-з'єднання зі зрізаними периими витками різьби муфти;

в -з'єднання з розтисканням перших витків муфти у радіальному напрямку; г-з'єднання з розтисканням останніх витків різьби ніпеля

\section{Рисунок 1 - Способи підвищення рівномірності розподілу навантаження між витками різьби муфтового 36єднання насосних штанг}

так і муфти) в процесі експлуатації. Зношуванню різьби також сприяє іï пошкодження та забруднення.

\section{Огляд способів зменшення нерівномірно-} сті навантажсення по витках різьби з'єднання насосних штанг

Руйнування різьбових з'єднань (особливо за знакозмінних навантажень) часто пов'язане iз значною концентрацією напружень у впадинах різьби та в місцях переходу від головки ніпеля до стрижня [3].

Для підвищення рівномірності розподілу навантажень по витках різьби з'єднання насосних штанг без зміни параметрів профілю різьби використовують такі техніко-технологічні способи.

1) Застосовують муфту розтягу-стиску із змінним перерізом розтягнутої частини.

Використання стиснуто-розтягнутих гайок дає змогу суттєво зменшити навантаження на перші витки різьби з'єднання і збільшити границю витривалості з'єднання на $25 . .30 \%$ [3] внаслідок більшої піддатливості перших витків різьби гайки. Можливість застосування муфти розтягу-стиску для з'єднання насосних штанг розглядалась у роботі [5], проте вона ускладнена малою товщиною муфти. На практиці можна виконати ділянку розтягу тільки над першими трьома витками різьби ніпеля (рис. 1, a).

2) Застосування муфти, виготовленої з матеріалу, модуль пружності якого відрізняється від модуля пружності матеріалу насосної штанги.

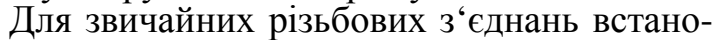
влено, що, застосовуючи гайки, 3 матеріалу модуль пружності та границя плинності якого менші порівняно 3 матеріалом болта, можна підвищити границю витривалості з'єднань на 15$20 \%$ [7]. Однак використання такого способу в з'єднанні насосних штанг можливе тільки тоді, коли буде забезпечений надійний захист муфти від зношування.
3) Покриття різьби муфти пластичним матеріалом.

Введення пластичних прошарків між витками болта і гайки (бронзування, алюмінування, цинкування, кадміювання) також дозволяе дещо вирівняти навантаження по витках різьби [8].

4) Зміна модуля пружності матеріалу ніпеля.

Для болтових з'єднань встановлено, що суттєве підвищення міцності з'єднання досягається збільшенням твердості матеріалу болта [3]. вання.

5) Вибір оптимальної довжини згвинчу-

Більша довжина згвинчування може дещо підвищити границю витривалості з“єднання при використанні матеріалу муфти з меншим модулем пружності, ніж матеріалу ніпеля [3].

6) Застосування різьби ніпеля, утопленої в різьбі муфти.

В таких з'єднаннях перший виток ніпеля більш піддатливий, що зменшує навантаження, яке діє на нього [3]. Застосовується в муфтових з'єднаннях нової конструкції [4].

7) Використання зрізу перших витків різьби муфти (рис. 1, б).

Зріз витків в найбільш навантаженій ділянці під кутом $10-12^{\circ}$ дозволяє зменшити дію навантажень на них і підвищити границю витривалості на $20 \%$ [3].

8) Розтискання перших витків різьби муфти у радіальному напрямку.

Відомі гайки з увігнутою опорною поверхнею [3, 8], яка дозволяє збільшити піддатливість перших витків і забезпечити обтискання останніх. Це сприяє вирівнюванню наванта-

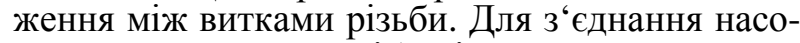
сних штанг цей спосіб здійснити важко через малу товщину муфти та площі контакту на стику з“єднання (рис. 1, в). Конструкція муфтового $3^{\star}$ єднання 3 конічним заплечником не застосовується [5]. 

муфти.

9) Обтискання останніх витків різьби

Відомі гайки [8] з обтисненими в радіальному напрямку останніми витками. Це дозволяє збільшити жорсткість останніх витків і зменшити навантаження на перші витки. Для $3^{6} є$ днання насосних штанг обтискання останніх витків можна забезпечити, застосовуючи муфти розтягу-стиску.

10) Розтискання останніх витків різьби ніпеля.

Ефект від використання даного способу аналогічний до наведеного вище способу. Для

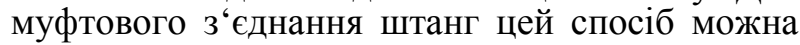
реалізувати за допомогою наявності в муфті спеціальної конусної вставки (рис. 1, г). Однак практично реалізувати його досить важко, тому що необхідна підвищена точність виготовлення і складання деталей.

11) Попереднє пластичне деформування перших витків ніпеля або муфти.

При попередньому обтисканні 3“єднання високими зусиллями згвинчування, відбувається пластична деформація перших витків $3^{‘}$ єднання. При подальшому прикладенні нормального зусилля згвинчування, навантаження

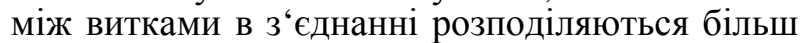
рівномірно. В результаті аналізу пружно-

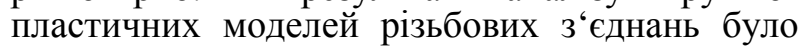
висловлено припущення, що попереднє обтискання 3“єднань високими зусиллями згвинчування можна використовувати для зміцнення

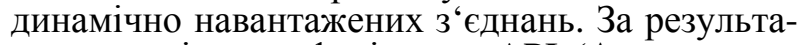
тами досліджень фахівцями АРI (Американський нафтовий інститут) розроблені рекомендації величин надлишкового моменту згвинчу-

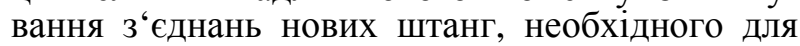
зминання первинної шорсткості витків різьби і торців поверхонь.

Можливе також одночасне поєднання кількох способів вирівнювання розподілу навантажень по витках різьби.

\section{Викладення основного матеріалу}

Дослідження напруженого стану конструкції різьбового з'єднання насосних итанг

3 метою визначення розподілу напружень, що виникають у конструкції різьбового з'єднання насосних штанг (19 мм), проведено імітаційне моделювання. Для цього у програмному середовищі SolidWorks здійснено побудову тримірної моделі конструкції різьбового з'єднання насосних штанг, яка зображена на рис. 2.

Зважаючи на те, що при проведенні імітаційного моделювання конструкція різьбового з'єднання навантажуватиметься тільки моментом згвинчування, тримірну модель спрощено до осесиметричної (рис. 3).

Матеріалами для ніпеля та муфти прийнято сталь 3 такими фізичними властивостями: $\mathrm{E}=2,1 \cdot 10^{11}$ Па; $\mu=0,28 ; \sigma_{\mathrm{T}}=620 \mathrm{M \Pi а}$.

Граничними умовами для з'єднання прийнято фіксацію моделі по торцю муфти та момент згвинчування. Імітація моменту згвинчування проводилась шляхом перекриття торців

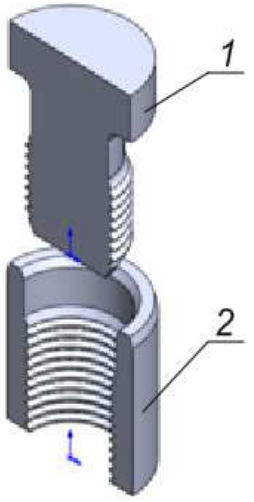

a)

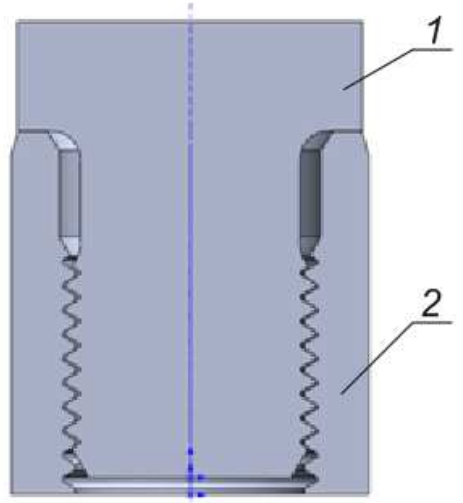

б)
1 - ніпель; 2 -муфта;

а) - у розібраному виді; б) - у зібраному вид $i$

Рисунок 2 - Тримірна модель ніпеля та муфти

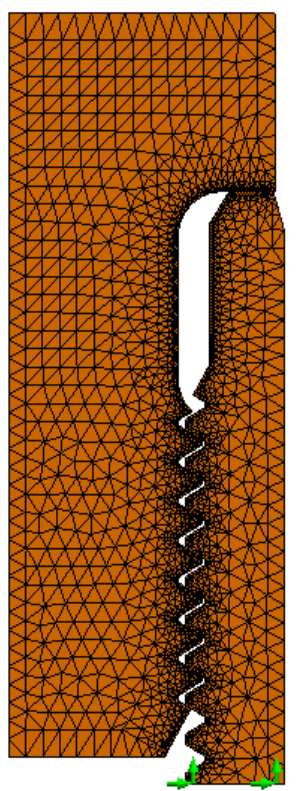

Рисунок 3 - Осесиметрична модель конструкції з'сднання з сіткою кінцевих елементів

ніпеля та муфти з застосуванням меню програми «гарячая посадка».

Коефіцієнт тертя між всіма контактуючими поверхнями (витками різьби та упорними торцями ніпеля і муфти) прийнято рівним 0,15. Під час розбиття моделі з'єднання на сітку кінцевих елементів (рис. 3) використано «елемент керування сіткою», що дало змогу збільшити кількість елементів сітки у зонах контакту витків різьби ніпеля та муфти та їх торців і отримати більшу точність результатів.

У результаті імітаційного моделювання отримано такі епюри: (рис. 4);

- еквівалентних напружень (за Мізесом)

- переміщень (рис. 5);

- деформацій (рис. 6).

Для встановлення величин напружень у впадинах витків різьби ніпеля та побудови графічної залежності їх розподілу (рис. 13, залежність 1) застосовано меню «зондирование» (рис. 7). 
von Mises $\left(\mathrm{N} / \mathrm{mm}^{\wedge} 2(\mathrm{MPa})\right]$
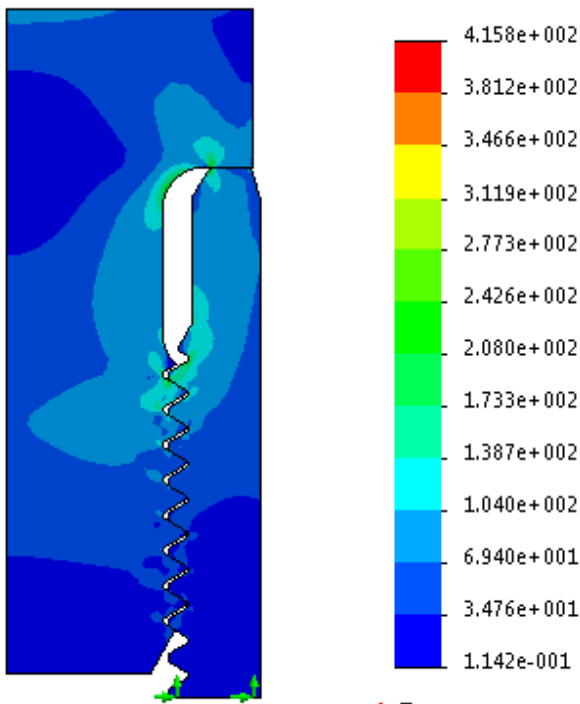

$\longrightarrow$ Предел текучести: $6.204 \mathrm{e}+002$

Рисунок 4 - Розподіл еквівалентних напружень у конструкції з'сднання

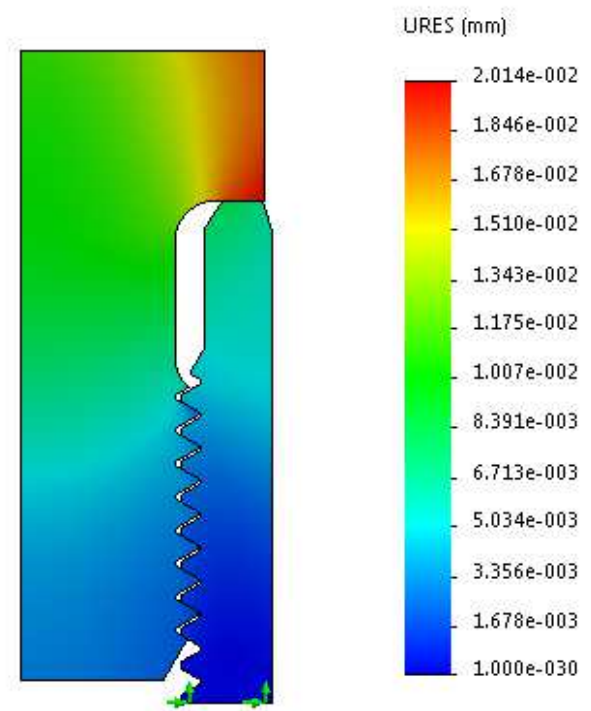

Рисунок 5 - Переміщення у конструкції з'сднання

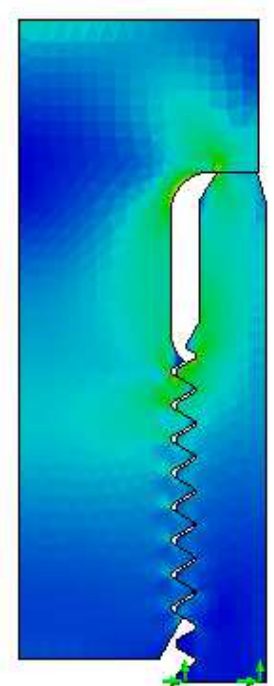

ESTRN

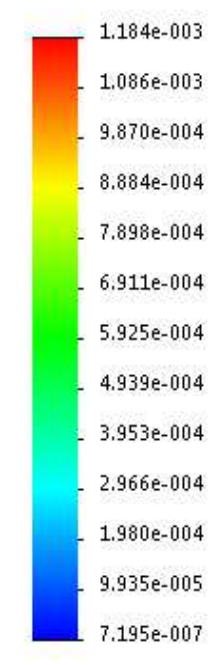

Рисунок 6 - Деформація у конструкції з'єднання
Як бачимо, розподіл еквівалентних напружень по впадинах різьби ніпеля у стандартній конструкції з'єднання відбувається нерівномірно, і основне навантаження прикладене до трьох перших від упорного торця ніпеля витків (рис.13). Отримані результати імітаційного моделювання корелюються 3 теорією А. I. Біргера [3], що підтверджує правильність побудови кінцево-елементної моделі конструкції різьбового з'єднання НШ.

Отже, з метою підвищення експлуатаційної надійності різьбового з'єднання необхідно удосконалити його конструкцію таким чином, щоб забезпечити рівномірний розподіл напружень по впадинах витків різьби.

Вдосконалення існуючої конструкції різьбового з'єднання насосних итанг

Характер розподілу навантаження між витками різьби є однією 3 оцінок досконалості динамічно навантажених різьбових 3'єднань [3].

На розподіл зусиль між витками різьби, перш за все впливають конструктивні параметри самого з'єднання [3], а саме:

- висота контактуючої різьбової частини;

- товщина стінки муфти;

- крок різьби;

- профіль різьби; муфта;

- матеріал, з якого виготовлені ніпель та

- точність виготовлення різьби.

Для зміни розподілу навантажень по витках різьби використовують також змінний середній діаметр різьби муфти $[3,9]$. Застосувати змінний середній діаметр різьби можна і на ніпелі НШ. Для цього пропонується у тілі ніпеля виконувати отвір на глибину 20 мм та діаметром 16 мм. (рис. 8). Всередину отвору за допомогою посадки 3 натягорізняєтьс від циліндричного та буде визначено за допомогою імітаційного моделювання.

За граничних умов аналогічних тим, що застосовані при дослідженні напруженодеформованого стану стандартного різьбового з'єднання насосних штанг, проведено імітаційне моделювання для удосконаленої конструкції (рис. 8-12).

Як і для стандартної конструкції різьбового з'єднання, побудовано графічну залежність розподілу еквівалентних напружень по впадинах витків ніпеля для удосконаленої конструкції (рис. 13, залежність 2). Як бачимо 3 рис. 13, в удосконаленій конструкції з'єднання НШ порівняно із стандартною спостерігається більш рівномірний розподіл напружень по впадинах витків різьби ніпеля та зниження величин напружень у першому витку в межах 60 МПа.

На рис. 14 зображено схему додаткового елемента 3 поверхнею, профіль якого був визначений за допомогою параметричного дослідження.

Як свідчать промислові дані та аналітичні розрахунки різьбових з'єднань, зменшення напружень у першому витку та їх рівномірний розподіл по всіх витках з'єднання сприятиме 


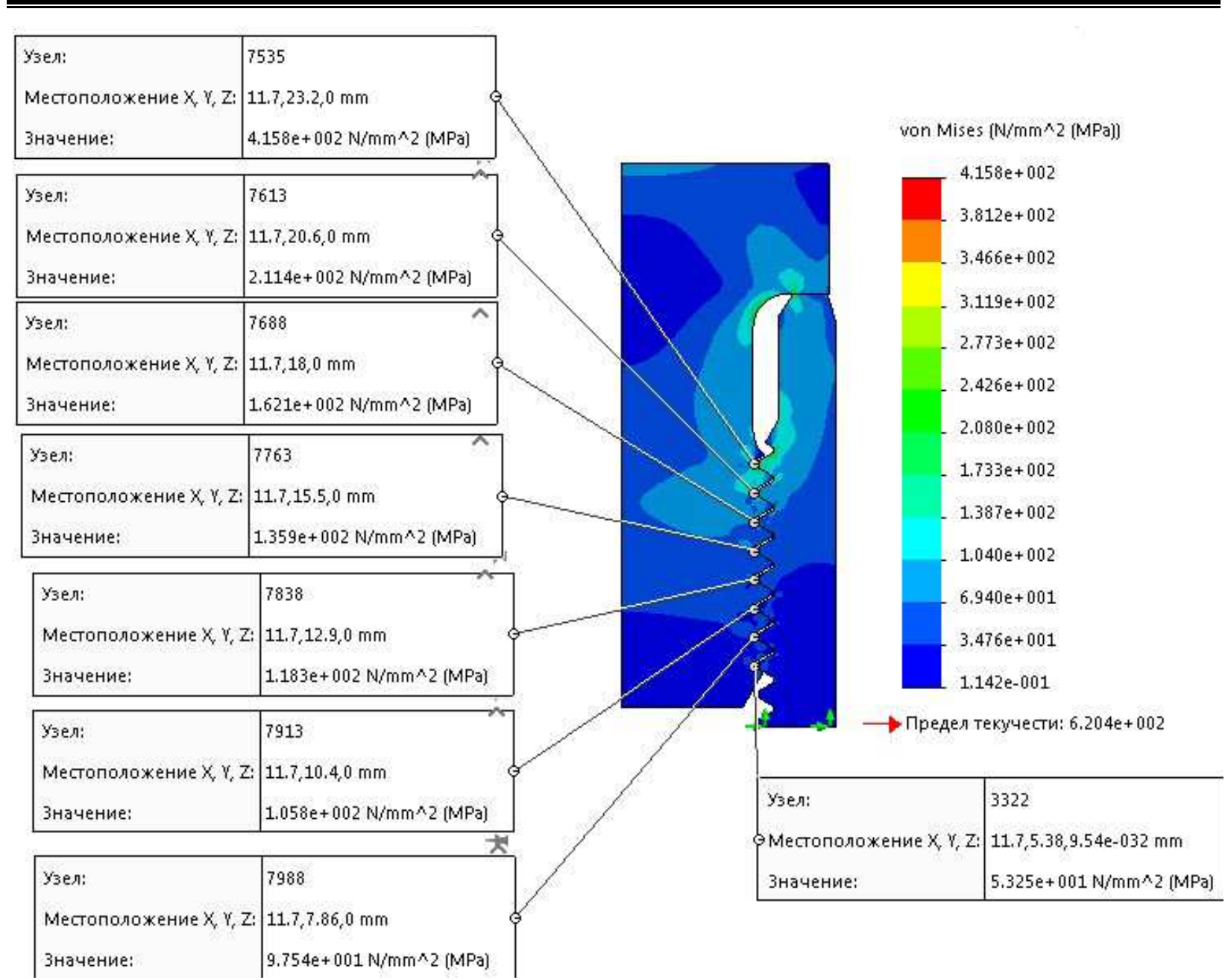

Рисунок 7 - Точки заміру величин напружень

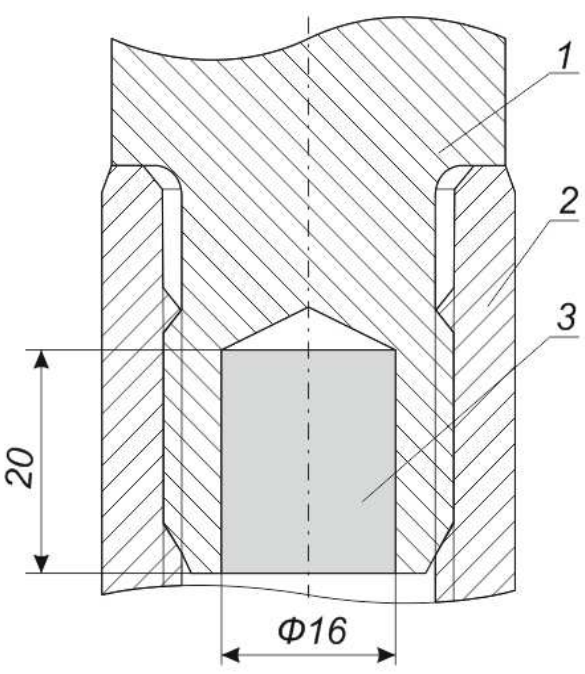

1 - ніпель; 2 -муфта; 3 - вставний елемент

Рисунок 8 - Запропонована конструкція різьбового з'єднання насосних штанг

збільшенню довговічності з'єднання, особливо при дії знакозмінних циклічних навантажень.

Однак, одним із визначальних факторів працездатності запропонованої конструкції різьбового з'єднання є спосіб посадки додаткового елемента в отворі ніпеля. Тому пропону-

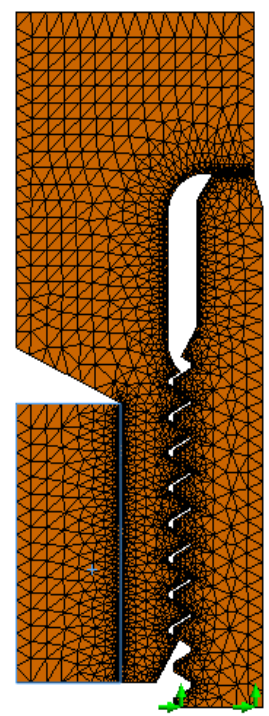

\section{Рисунок 9 - Осесиметрична модель 3 сіткою кінцевих елементів}

ється встановлювати додатковий елемент тільки 3 його охолодженням або нагріванням ніпеля. Виконання посадки додаткового елементу 3 натягом за допомогою пресу категорично заборонено. 


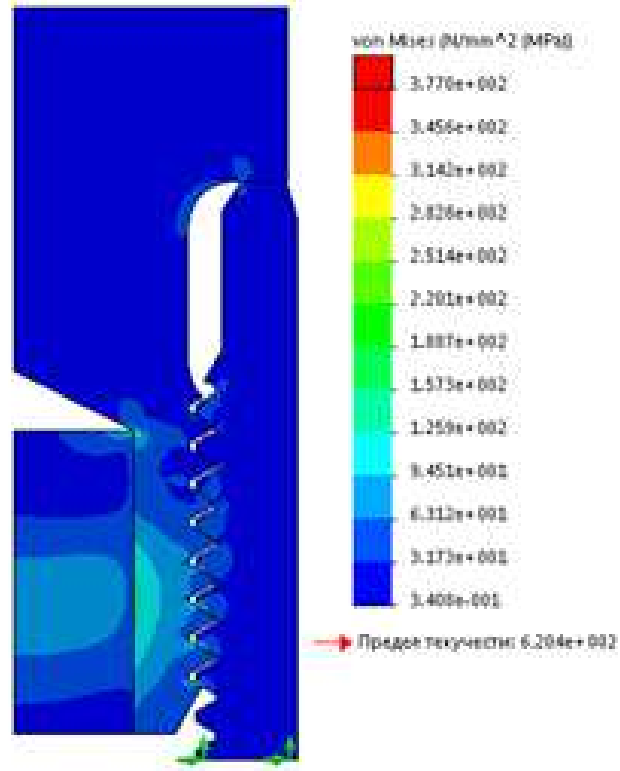

Рисунок 10 - Розподіл еквівалентних напружень у поперечному перерізі запропонованої конструкції різьбового з'сднання

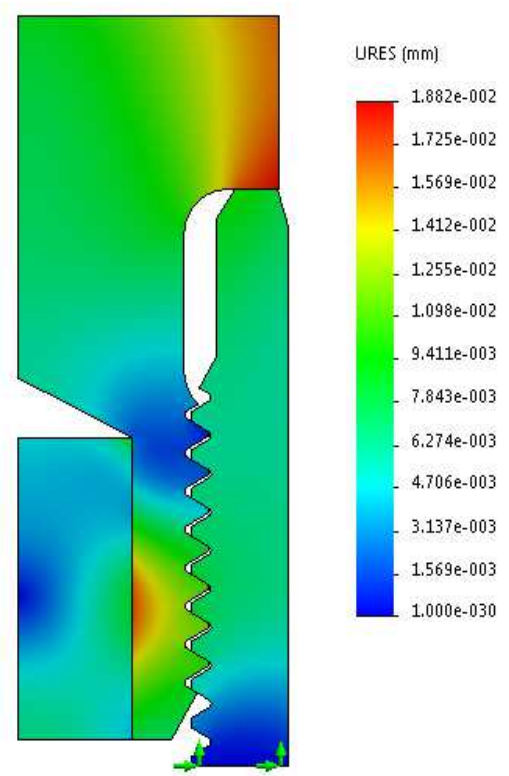

Рисунок 11 - Переміщення

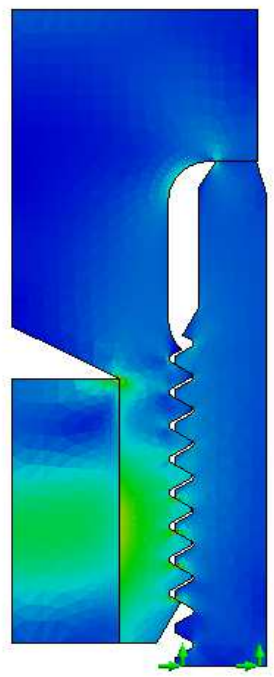

Рисунок 12 - Деформація

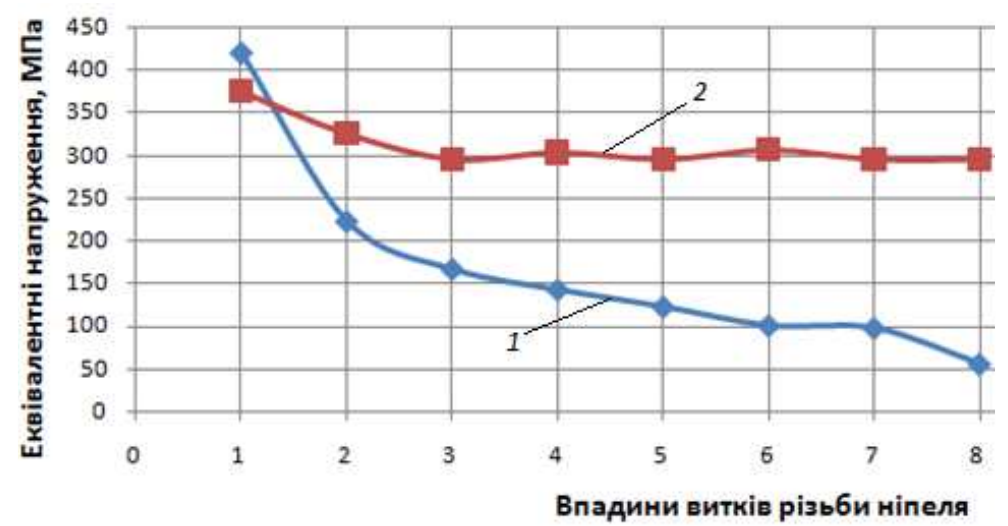

1 - стандартне; 2 - запропоноване

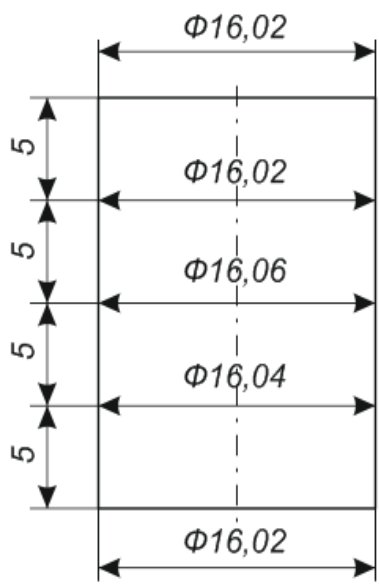

Рисунок 14 - Додатковий елемент 3 профільною поверхнею

\section{Висновки}

На основі аналізу літературних джерел встановлено основні типи відмов елементів колони насосних штанг та встановлено, що близько третини 3 них припадають на відмови різьбових 3'єднань. Перш за все, ці відмови пов'язані із нерівномірність розподілу навантажень по витках з'єднання НШ.

За результатами імітаційного моделювання стандартного 3'єднання насосних штанг побудовано графічні залежності розподілу напружень по впадинах різьби ніпеля, що виникають тільки від дії моменту згвинчування з'єднання. Отримані результати добре корелюються 3 теорією А. І. Біргера, що підтверджує правильність побудови кінцево-елементної моделі. 
На основі аналізу існуючих способів зменшення нерівномірності розподілу навантажень по витках різьби запропоновано конструкцію з'єднання НШ, в якій різьба ніпеля має змінний середній діаметр. За результатами імітаційного моделювання встановлено геометричні розміри додаткового елементу, що встановлюється 3 натягом у отвір, виконаний у тілі ніпеля.

Таке удосконалення конструкції з'єднання призводить до зниження напружень у першій впадині витка ніпеля на величину близько 60 МПа. В третьому та наступних витках ніпеля напруження зростають та вирівнюються по величині. Вирівнювання напружень по впадинах витків позитивно впливатиме на роботу з'єднання насосних штанг при дії циклічного навантаження.

Подальші роботи будуть спрямовані на дослідження впливу інших видів навантажень на експлуатаційні характеристики удосконаленої конструкції з'єднання НШ та його довговічність.

\section{Лimepamypa}

1 Копей В. Аналіз відмов колон насосних штанг в НГВУ "Долинанафтогаз" / Володимир Копей, Іван Стеліга // Розвідка та розробка нафтових і газових родовищ. - 2002. - № 4(5). C. $78-80$.

2 Тараевский С. Анализ поломок глубинно-насосных штанг в НГДУ “Долинанефтегаз” / С. И. Тараевский, Б.В. Копей // Разведка и разработка нефтяных и газових месторождений. 1982. - Вып.19. - С.104-107.
3 Биргер И.А. Резьбовые и фланцевы есоединения / Биргер И.А., Иосилевич Г.Б. - М.: Машиностроение, 1990. - 368 с.

4 Штанги насосные и муфты штанговые. Технические условия. Sucker rod sand sucker rod couplings. Specifications: ГОСТ 13877-96 [Взамен ГОСТ 13877-80; Введ. 01.01.2001]. М.: Изд-востандартов, 2001., - 33 с.: ил.

5 Фаерман И. Л. Штанги для глубинных насосов / И.Л. Фаерман. - Баку: Азнефтеиздат, 1955. $-323 \mathrm{c}$.

6 Круман Б.Б. Глубинно-насосные штанги / Б.Б. Круман. - М.: Недра, 1977. - 181с.

7 Якушев А.И. Повышение прочности и надежности резьбовых соединений / А.И. Якушев, Р.Х. Мустаев, Р.Р. Мавлютов. М.: Машиностроение, 1979. - 215 с., ил.

8 Орлов П.И. Основы конструирования. Справочно-методическое пособие в 3-х книгах. Кн. 2. Изд. 2-е, перераб. и доп. / П.И. Орлов. М.: Машиностроение, 1977. -574 с. с ил.

9 Михайлюк В.В. Розроблення різьбового з'єднання насосних штанг з рівномірним розподілом зусиль між витками різьби / Михайлюк В.В. // Науковий вісник ІФНТУНГ. - ІваноФранківськ: - 2010. - №4(26). - С. 61-65.

Стаття надійшла до редакиійної колегії 20.04.18

Рекомендована до друку професором Івасівим В.М. (ІФНТУНГ, м. Івано-Франківськ) канд. техн. наук Онишуком С.Ю.

(ПП «Група БРАСС», м. Івано-Франківськ) 